\title{
A fantázia határtalan - számvitel diákszemmel
}

\author{
Szarvas-Fekete Tibor, ${ }^{1}$ Ágoston Anita, ${ }^{2}$ Wickert Irén ${ }^{3}$
}

\begin{abstract}
Fantasy Unlimited - Accounting with a Student's Eye. "A talent is someone who knows more than they had learned", quoted the jury of the „Dal 2017” in the finals, after we saw the great performance of a 17 year old boy. What skills do the students of Kaposvár University have? How much part of their performance during the exams is knowledge and how much is fantasy? Adopting Henry Ford's witticism we can expect that smart, diligent students will do themselves justice and get good grades; the lazy and less talented students will vegetate whereas the hard-working but untalented students will fall out of the sieve. However, what about smart, but lazy students? Those who "forget" to learn but due to their powerful imagination, can create something unbelievable during the exam, overcoming the greatest cruxes in the good sense. This article deals with this theory in humorous form: what the accounting is like with the eyes of a clever, creative but lazy student.
\end{abstract}

Keywords accounting, students, examining, creativity

\section{Bevezetés}

„Sok van mi csodálatos, de az embernél nincs semmi csodálatosabb”, írta Szophoklész. Az ember alkotó, fantáziadús gondolkodó, aki a legváratlanabb helyzetekben is maradandót tud alkotni. Felvetődik a kérdés, hogy milyen ember típus tud a leghatékonyabban alkalmazkodni a környezetéhez, ezáltal milyen eredményeket tud elérni.

Henry Ford, az autóipar megálmodója és megvalósítója négy kategóriába sorolta az embereket.

- Az első kategória az okos-szorgalmas típus, akik hatékonyan, kreatívan dolgoznak, ezáltal ragyogó eredményeket érnek el. Véleménye szerint kevesen rendelkeznek e nem mindennapi képességekkel, természetesen a jelenlévők mindig kivételt képeznek.

${ }^{1}$ Kaposvári Egy etem, Gazdaságtudományi Kar

E-mail: szarvasfekete.tibor@ke.hu

2 Kaposvári Egy etem, Gazdaságtudományi Kar

E-mail: agoston.anita@ke.hu

${ }^{3}$ Kaposvári Egy etem, Gazdaságtudományi Kar

E-mail: wickert.iren@ke.hu 
- A második csoportba tartoznak a buta-lusta emberek. Ez az a kategória, amelynek nagyságrendje jelentős, és ők alkotják azokat a munkavállalókat, akik a futószalag mellett megfelelő irányítás ás ellenőrzés mellett hatékony munkavégzésre képesek.

- A harmadik csoportba tartozók a buta-szorgalmas emberek. Ök azok, akik szorgalmuknak köszönhetően halmozzák a hibákat és ennek következtében hatalmas károkat okoznak. Az üzleti életben kerülni kell ennek a csoportnak a tagjait.

- A negyedik kategória az okos-lusta csoport. Sok ész, kreatív és fantáziadús gondolkodás jellemzi a csoport tagjait, viszont lustaságuknak kös zönhetően csak megfelelő ösztönző módszerekkel lehet hatékony munkavégzésre bírni őket (Ford, 2013).

Henry Ford nem hitt a könyvelökben, mert úgy érezte, hogy nem eléggé hatékonyak, és végső soron több pénzt kell nekik fizetni, mint amennyi hasznuk van. Ennek ellenére mi hisszük, hogy a számviteli ismeretek hatékonyan alkalmazhatóak a vállalkozások müködésében, így a számviteli, adózási és pénzgazdálkodási ismeretek legalább alapszintü elsajátítására szeretnénk ösztönözni a diákokat.

\section{Számvitel diákszemmel}

Feltételezzük, hogy a Kaposvári Egyetem diákjainak nagy része a negyedik kategóriába tartozik. Hogyan boldogulnak az okos, de lusta diákok? Ök azok, akik ,elfelejtenek” tanulni, azonban hatalmas fantáziájuknak, rögtönző képességüknek köszönhetően a tantárgyi számonkérés során nagyot alkothatnak, túlszárnyalva ezzel a józan ész legmagasabb akadályait is.

Az elmúlt évek vizsgaeredményeit figyelembe véve, az ott elhangzottakra hivatkozva került összeállításra ez a tanulmány. A számvitel, adótan, ellenőrzés és pénzgazdálkodás tantárgyak vizs gakérdés eire adott válaszok megjelenítik ezen tantárgyak szépségeit és buktatóit is.

Dick Armey amerikai politikus a legenda szerint egyszer alábbiakkal jellemezte a számvitelt: „A számvitel az a tudomány, amely közismert dolgokat magyaráz el teljesen érthetetlen módon."

Elemezve az állítást, a „közismert” és az ,érthetetlen” szó az, ami gondolkodásra készteti az embert.

Vajon a diákok miként találnak utat a számvitel útvesztőiben, rendszertelen tanulással el tudják-e sajátítani a tananyagot.

Hipotézis eink:

- A számvitel tökéletes elsajátításához nem szükséges alaposabb tanulás, mint a többi tantárgy esetében.

- A Kaposvári Egyetem diákjainak fantáziája - főleg a nem tudás árnyékában határtalan.

Mielőtt részletesen megvizsgálnánk a vizsgakérdésekre adott válaszokat, tegyük tis zteletünket Luca Pacioli (1. kép) előtt, megemelve kalapunkat a számvitel atyja előtt, és kérjük feloldozását az esetleges számvitelt sértő eretnekségünkért. 
1. kép: Luca Pacioli (1445-1514)

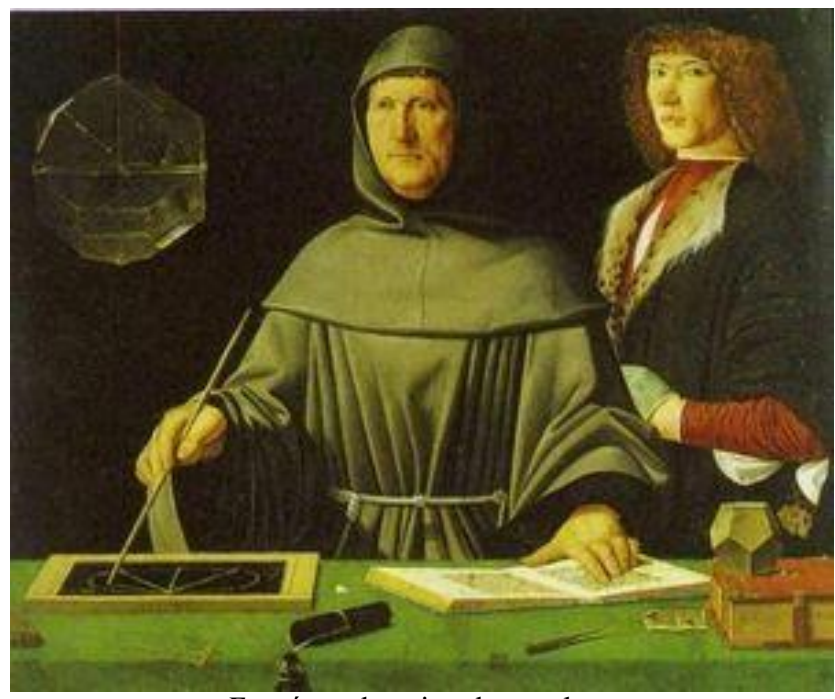

Forrás: e-ducation.datapeak.net

\section{Vizsgakérdések és válaszok - avagy a számviteli fogalmak újraértelmezése}

A számvitel vizsga általában írásban történik. A vizsga előtt az utolsó gyakorlaton konzultációra kerül sor, melynek során a hallgatók tehetnek fel kérdéseket az oktatók felé. Általában síri csend uralkodik, úgy néz ki, hogy minden hallgató mindent ért, nincs problémája. Később persze kiderül a csend oka, ugyanis kérdezni is csak az tud, aki már tanult. A csendet megtörve az oktató felhívja a figyelmet, hogy milyen jellegü vizsgára készüljenek, átismétli a korábbi évek tapasztalatai alapján a hallgatók számára bonyolultabb témákat.

Eljön a vizsgaidőszak, a hallgató bejelentkezik vizsgázni. A kiosztott vizsgasorok áttekintése után furcsa ábrázatú hallgatókat lehet látni, melyet egy karikatúrával szeretnénk szemléltetni.

\section{A számvitel célja}

A számvitel oktatás keretén belül első lépésben mindig szeretnénk bemutatni, hogy mi is tulajdonképpen a számvitel és milyen célja van. Az egyes vállalkozások tevékenységük során nagyon sok partnerrelállnak kapcsolatban. Megkülönböztetünkbelső és külső érdekhordozókat, de közös jellemzőjük, hogy szeretnék megismerni a vállalkozás müködését. Ezért az első előadáson ismertetjük az alapvető fogalmakat, köztük az alábbi definíciót.

A számvitel célja információszolgáltatás az érdekelteknek. (Baricz-Róth, 2006)

Hogyan értelmezi ezt a hallgató, avagy tanulás nélkül mi marad meg az emlékezetében? Válasz:

A számvitel célja: „Információ-kielégítés” 


\section{Mérleg}

A következő alapvető definíció, melyet minden hallgatónak el kell sajátítania ahhoz, hogy szélesebb körü számviteli ismereteket szerezhessen, az a mérleg fogalma.

A mérleg

- meghatározott formátumú számviteli okmány,

- amely az eszközöket és forrásokat,

- adott időpontra vonatkozóan,

- összevontan és

- pénzértékben tartalmazza. (Baricz-Róth, 2006)

El kell ismernünk, hogy ez egy igen hosszú meghatározás, fóként akkor, ha a diák „elfelejtett” tanulni. Nem elvárható, hogy teljes pontossággal emlékezzen valaki ezen eszmefuttatásra. Lássuk hát mi ragadt meg az emlékezetükben.

Mit nevezünk mérlegnek?

Az alábbi válaszok születtek:

„Eszközök és források viszonyában kifejezett könyvelési eszköz.”

„Számviteli okmány, amely tartalmazza a tartozik és követel oldalt.”

Mindkét definíció tartalmaz igazságokat is, hiszen valóban eszközöket és forrásokat jelenítünk meg a mérlegben, valamint számviteli okmány. A kreatív diák azonban az órákon összeszedett „tudás” segítségével próbálja kiküszöbölni a fogalom többi részét érintő hiányos ságait.

\section{Eredménykimutatás}

Az eredménykimutatás az eredmény összetevőit mutatja. Egy olyan számviteli okmány, amely meghatározott szerkezetben egy adott időszak hozamait, ráfordításait és eredményét mutatja pénzértékben kifejezve. A definíció a mérleg fogalmának összetettségéhez hasonlít, így a hallgatók ismét a kreatív gondolkodást ötvözték a csekély mértékủ ismereteikkel.

Mit nevezünk eredménykimutatásnak?

Válasz:

„A mérleg utolsó napi jövedelmének kimutatása.”

Ebből a megoldásból érződik, hogy valamit sejt a hallgató, de nehéz azt egységes keretbe foglalnia. Tényleg megjelenik az eredmény, hiszen ez az eredménykimutatás célja, és bizonyos eseteken ez eredményesség és a jövedelmezőség fogalmát szinonimaként használják. Abban is igaza van a hallgatónak, hogy a tárgyév eredménye megjelenik a mérlegben a saját tőke elemei között. A probléma csupán, hogy a részinformációkból összerakott fogalmának semmi értelme nincs.

\section{Bevétel}

Az eredménykimutatásról már szó volt, így nem hagyhatjuk ki a bevétel fogalmát s em. Elsőre általában problémát okoz a bevétel és hozam fogalmának elkülönítése. A bevétel az értékesítéshez, realizáláshoz kapcsolódó fogalom, magába foglalja: az értékesítés nettó árbevételét, egyéb bevételeket, a pénzügyi bevételeket. A hozam pontos definíciója: a kibocsátott - értékesített, realizált - termékek, teljesítmények ellenértéke. A bevételek fogalma a számvitelben nem egyezik meg a pénzbevételekkel, mert

- a bevétel időben megelőzheti a pénzbevételt, 
- a bevétel és a pénzbevétel időben egybeeshet,

- a bevétel időben követheti a pénzbevételt.

A vizsgán tapasztalt megoldásokból az derül ki, hogy ez együttesen már túl sok információt jelent azon hallgatók számára, akik a rendszertelen tanulás módszerében hisznek. Ennek következtében mindenből csippentve egy kicsit, egy sajátos definíciót kapunk a bevétel meghatározására.

Mit hívunk bevételnek?

Válas zok:

„Reálisan eladott termék pénzben való kapott értékét.”

„Olyan tárgyi, anyagi változás, melynek hatására a vállalat vagyona megnő.”

\section{Idősoros elszámolás}

A hallgatók a félév során nemcsak elméleti, hanem gyakorlati ismereteket is elsajátítanak. Ennek ellenére szükség van egy alapozó tudásra, melyet a későbbiekben a feladatok megoldása során hasznosíthatnak. Így kerül elő az idősoros elszámolás fogalma, mely csupán annyit jelent, hogy időrendi sorrendben történik a vállalkozást érintő gazdasági es emények könyvelése. Ha a diáknak azonban nem jut eszébe a kérdés megoldása, akkor a fantázia szárnyalásának következtében az alábbi érdekes meghatározás születhet.

Mit nevezünk idősoros elszámolásnak?

Válasz:

„Meghatározott időszakban rendezzük a tartozást, negyedéves, féléves, éves.”

Tulajdonképpen ez egy igen gyakorlatias megoldás, hiszen a tartozásainkat többnyire időrendi sorrendben rendezzük.

\section{Számla (kontó)}

A könyvelés fogalmai között merül fel a számla definíciója is, mely a gazdasági események könyvviteli szabályok szerint történő rögzítésének az eszköze. (Baricz-Róth, 2006) A hallgatókkal fókönyvi számlákon vezetjük a vállalkozáshoz kapcsolódó gazdasági eseményeket, melyek esetében az alapvető gazdasági eseményektől haladunk az összetettebb változások felé, melyek a vállalkozás jövedelmezőségét is érintik. A definíció azonban a könyvelés alapvető ismeretei nélkül nehezen megjegyezhető, ennek köszönhetően született az alábbi fantáziadús megoldás

Mit nevezünk számlának (kontó)?

Válasz:

„Gazdasági eszköz, amellyel kifejezzük a vállalkozás forgalmát.”

\section{Készpénz nélküli fizetési formák}

Hallgatóink nemcsak számviteli alapismereteket sajátíthatnak el a kurzusokon, hanem alapvető pénzügyi ismeretekre is szert tehetnek. Ennek keretében oktatjuk a pénzforgalom müködési rendszerét, köztük a készpénz nélküli fizetési formákat:

- átutalás

- beszedési megbízás (inkasszó)

- okmányos hitelezés (akkreditív)

- $\quad$ csekk (fizetési felszólítás) 
A hallgatók az első két pontot könnyen megjegyzik, azonban az okmányos hitelezés, vagy a csekk „eltünik” az elsajátított információ halmazban. Arra még emlékeznek, hogy idegen kifejezések is előfordultak a felsorolásban, de a pontos elnevezések már összemosódnak más tudományterületekről érkező ismeretekkel. Így fordulhatott elö, hogy az inkasszó és az impresszió találkozásából megszületett a jövő készpénz nélküli fizetési formája az,inpresszió”.

Sorolja fel a készpénz nélküli fizetési formákat!

Válasz:

- „Átutalás,

- Beszedési megbízás,

- Inpresszió."

\section{Az adóztatás alapelvei}

A pénzgazdálkodás témaköréhez tartozik az adózás is. Az adórendszer müködése minden országban központi kérdés, mivel az állam fő bevételi forrását a közhatalmi bevételek jelentik. A hatékony és etikus müködés érdekében az alábbi alapelveknek kell megfelelni az adóztatás során:

- közteherviselés,

- fizetőképesség,

- megbízhatóság. (Stiglitz, 2000)

Egy igazán lusta, de kreatív hallgató azonban az adórendszer elemeire és az etikus müködtetésre koncentrálva újra definiálta az alapelveket.

Sorolja fel az adóztatás alapelveit!

Válasz:

- „közteherviselés,

- jövedelemadó,

- társadalmi hovatartozás"

\section{A magyar bankrendszer}

Az alapvető pénzügyi ismeretek közé tartozik a bankrendszer átfogó megismerése. Hazánkban kétszintü a bankrendszer. A Jegybank (Magyar Nemzeti Bank) mellett kereskedelmi bankok, hitelintézetek vesznek részt a piac müködésében. A bankok az alábbi fóbb tevékenységeket végzik:

- passzív bankügylet (pl.: betétgyüjtés)

- $\quad$ aktív bankügylet (pl.: hitelnyújtás)

- fizetési forgalom lebonyolítása (pl.: elszámolási számla)

- $\quad$ egyéb bankszolgáltatás (pl.: trezor) (Ligeti - Sulyok-Pap, 2006)

A hallgatóinknak azonban más a véleménye a hazai bankrendszer működéséről, vagy egyáltalán a létezéséről.

Mi jellemzi a magyar bankrends zert?

Válasz:

- „Modern bankrendszer teljes hiánya,

- Banki ismeretek hiánya,

- Banküzemi korlát hiánya, 
- Korlátozott tevékenység,

- Forintot használunk."

\section{Biztosítás fogalma}

A pénzgazdálkodás kurzus keretein belül a hallgatók pát szóban megismerhetik a biztosítások jellemzőit, így a biztosítás fogalmát is. A biztosítás a kockázat felosztás módszerén alapuló pénzalapképzés a hozzájárulást fizetö (veszélyközösségi) tagok esetleges felmérhető és meghatározott szükségletének kiegyenlítése céljából.

A hallgatók azonban itt is több esetben a számviteli ,ismereteikre" próbálnak hagyatkozni, ennek következtében a fizetésre helyezik a fö hangsúlyt. Vannak azonban olyan diákok is, akik a definíciót tovább fejlesztve a biztosítások gyakorlati múködésére koncentrálnak, például a károk osztályozására.

Mi a biztosítás fogalma?

Válaszok különböző hallgatóktól:

„biztosítjuk az eladót a fizetés ről”

„,biztosítjuk a tárgy vagy készlet fizetéséről”

„kár szerint osztályozott pénz-alapképzés”

\section{Allatok}

A számvitel a diákok által kevésbé kedvelt területe a mezőgazdasági és ezen belül az állatokkal kapcsolatos gazdasági események elszámolása és az állatok besorolása, nyilvántartása. Az állatok elszámolását még tovább bonyolítja, hogy a jogszabály szerint megkülönböztetünk tenyészállatokat, melyeket a tárgyi eszközök között kell nyilvántartani, valamint növendék- és hízó-, és egyéb állatokat, amelyek forgóeszköznek minösülnek és a készletek között kerülnek kimutatásra.

A számviteli törvény szerint tenyészállatoknak minősülnek azok az állatok, amelyek a tenyésztés, tartás során leválasztható terméket termelnek és a tartási költségek ezen termékek értékesítése során megtérülnek, vagy az egyéb hasznosítás biztosítja a tartási költségek megtérülését, függetlenül attól, hogy mennyi ideig szolgálják a vállalkozási tevékenységet.

A növendék-, hízó- és egyéb állatok, azok az állatok amelyek a termelés (a tartás) költségei eredményeként növekednek, tömegük gyarapszik, függetlenül attól, hogy a vállalkozási tevékenységet mennyi ideig szolgálják,

Azállatok számvitele el kell ismerni nem egyszerü. A hallgatók nem szeretnek magolni, csak a fogalmakból szemezgetnek, hol sikeresen, hol sikertelenül, ennek megfelelö definíciókkal találkozhatunk a vizsgán.

Mi a tenyészállat?

Válasz:

„Tenyés zállatnak az az állat minősül, ami másodlagos terméket hagy maga után.”

Ismertesse az állatok számviteli elszámolásának rendszerét!

Válasz:

„Az állatokat az 5-ös számlaosztályban tartjuk nyilván, azonban, ha sokan vannak, akkor a 6-os és 7-es számlaosztályt is igénybe vesszük." 


\section{Ellenörzés}

Az ellenőrzés tantárgy keretében ellenőrzési programot, vizsgálati jelentést és bizonyító erejü okiratot kell elkészíteni a hallgatóknak. A vizsgálati jelentésben hibákat kell megnevezni, és ezeket dokumentálni. Mivel a nappali tagozatos hallgatók gyakorlati tapasztalatokkal nem rendelkeznek, így a vizsgadolgozat részben a képzelet szüleménye.

Idézetek a vizsgadolgozatokból az elkövetett hibákkal kapcsolatban:

„Hibát követtem el, mert gyakori emlékezet kiesésben szenvedek.”

„Az érkezó árut átvevő raktáros veszi át a számlát is, majd, ha ráér, áthozza nekem az irodába."

„A számlák javításának szabályairól most hallottam először.”

\section{Feladás}

A feladás fogalma okozza az egyik legtöbb problémát az elméleti ismeretek elsajátítása során, mivel a definíció értelmezéséhez már szükség van a könyvelés alapvető összefüggéseinek megértésére. A feladás az analitikus könyvelés adatainak csoportosítása és összesítése, valamint átadása a szintetikus könyvelés céljára. A definíció értelmezéséhez a hallgatónak ismernie kell a kettős könyvvitel zárt rendszerének felépítését, ennek hiányában azonban kreatív, illetve gyakorlatias megoldások születnek a vizs gákon.

Mit nevezünk feladásnak?

Válaszok:

„Számla átadását az analitikus nyilvántartás számára.”

„Egy csekk, vagy számla értékének a kifizetését.”

„Vagyontárgyak postai úton történő továbbítása."

„Pénzeszközök sárga csekken történő feladása.”

A válaszok alapján úgy érzem, hogy a szakterület bemutatását már én is feladom, de e tekintetben is megelöztek.

Van olyan szituáció, amikor a hallgató már tényleg nem érzi annak a lehetőségét, hogy az emlékezetéből elő tudná keresni a definíciót, így a feladja a próbálkozást, és a legalapvetőbb gyakorlati meghatározást ismerteti a számonkérés során.

„Ha valami cél érdekében tett erőfeszítésünket végleg abba hagyjuk.”

Ilyenkor dől össze a világ. A diák boldog, hogy talán átment a vizsgán, a tanár tanácstalan. Talán többet kellene előadásra járni, talán folyamatosan kellene tanulni.

Egy biztos, ,a diákok fantáziája - föleg a nem tudás árnyékában - HATÁRTALAN". Mit lehet tenni? Erre a következő kérdésre adott válasz a megfelelö.

Mit jelent a SEEAÉ?

Válasz:

- „Ez egy rövidítés!”

• „SEGITSÜK EGYMÁST AMÍG ÉLÜNK!”

A vizsgadolgozatokban feltett kérdésekre adott válaszok alapján megvizsgáltuk, hogy a megfogalmazott két hipotézist az eredmények milyen mértékben igazolták.

1. A számvitel tökéletes elsajátításához nem szükséges alaposabb tanulás, mint a többi tantárgy esetében. 
A hallgatói válaszokra támaszkodva megállapítottuk, hogy előzetes feltételezéseinkkel ellentétben a számvitel tökéletes elsajátításához alaposabb tanulás szükséges, mint általában a többi tantárgy esetében.

2. A Kaposvári Egyetem diákjainak fantáziája - föleg a nem tudás árnyékában - HATÁRTALAN.

Az évek során szerzett gyakorlati tapas ztalat és a számviteli vizs gák során összegyüjtött információk alapján igazolást nyert, hogy a Kaposvári Egyetem diákjai határtalan fantáziával rendelkeznek.

\section{Összefoglalás}

Aki nevetni tudott a válaszokon, ő feltehetően a számvitelnek nem csak a dallamát érti. Aki felháborodott - tudomány, vagy áltudomány - lazítson, néha kell egy kis pihenés! És hogy ki kacag, vagy ki sír a történteken, azt majd a számvitel jövője fogja eldönteni. Legtöbb diák, aki a számvitelt kényszerből tanulja, csak arra fog emlékezni: Tartozik Követel

Erősítse meg számvitel iránti hitünket Goethe bölcs gondolata:

„A számvitel az emberi szellem legcsodálatosabb találmánya.” (Goethe)

\section{Források}

Baricz R. - Róth J. (2006): Könyvviteltan. Budapest, Aula Kiadó.

Ford, H. (2013): My Life \& Work - An Autobiography of Henry Ford, CreateSpace Independent Publishing Platform.

Ligeti S. - Sulyok-Pap M. (2006): Banküzemtan, Budapest, Pénzügyi Tanácsadó és Szolgáltató.

Stiglitz, J. E. (2000): A kormányzati szektor gazdaságtana. Budapest, KJK-Kerszöv Jogi és Üzleti Kiadó Kft..

2000. évi C. törvény a számvitelről.

A müre a Creative Commons 4.0 standard licenc alábbi típusa vonatkozik: $\underline{\text { CC-BY-NC-ND-4.0. }}$. 